\title{
"Populista não, popular!": Imagens político-eleitorais em disputa no YouTube e na TV
}

\section{Teresinha Maria de C. Cruz Pires}

\section{Resumo}

Este artigo trata da midiatização do discurso político na campanha eleitoral municipal de Belo Horizonte, de 2008, mais especificamente das estratégias discursivas de (des)construção de imagens mobilizadas por dois dos candidatos. Estratégias essas consideradas singulares e relevantes por evidenciarem transformações no discurso e no modo de produção da política, seja pela apropriação das novas mídias - no caso, examina-se uma estratégia complexa de campanha negativa no ambiente do YouTube: uma sátira paródica que se apropria do Horário Gratuito Político Eleitoral (HGPE) do adversário, num nível metadiscursivo; seja pelo recurso à estética e à linguagem do popular massivo como estratégia de construção de imagem no HGPE da televisão. Interessa-nos, ainda, demonstrar como essas estratégias midiáticas, tão contemporâneas, recobriram o velho e tradicional discurso populista.

\section{Palavras-chave}

Discurso político. Imagens políticas. Campanha eleitoral municipal. Campanha Negativa. Midiatização da política.
Teresinha Maria de C. Cruz Pires I pires@pucminas.br

Pontifícia Universidade Católica de Minas Gerais. Possui graduação em Comunicação Social - Jornalismo - pela Universidade Federal de Minas Gerais (1983), mestrado em Sociologia pela Universidade Federal de Minas Gerais (1992) e doutorado em Comunicação pela Universidade Federal do Rio de Janeiro (2002). Professora do Programa de Pós-graduação em Comunicação Social da PUC Minas; desenvolve pesquisas na área de comunicação e política e integra 0 grupo de pesquisa do CNPq Mídia e Narrativa.

\section{Introdução}

Este artigo tem como proposta analisar uma disputa pública por imposição de imagens políticas por ocasião de uma campanha eleitoral de âmbito municipal. Postula-se, aqui, a partir de Marilena Chaú, que "a competição pública não se faz entre partidos, ideologias ou candidatos, mas entre imagens que disputam valores como 'credibilidade', 'confiabilidade', 'respeitabilidade', ‘inovação', 'prestígio"' (CHAUÍ, 1992, p. 386). Imagens são também discursos e, discursos, disputam sentidos. Aliás, como sublinha Murray Edelman $^{1}$ (apud, MIGUEL, 2000, p. 60): "0 elemento crítico nas manobras políticas é a criação de sentido". Sentido, esse, estabelecido por meio de uma acirrada batalha política na qual

Algumas palavras são bens altamente valorizados [...] e cada um que se dispõe a se associar a elas torce-Ihes o sentido [...] Assim, a disputa em torno de palavras e um grau razoável de imprecisão no seu uso, são inevitáveis: essa disputa é constitutiva do próprio discurso político. (MIGUEL, 2000, p. 66)

Interessa-nos, a seguir, tratar de uma disputa política - específica - de sentidos e de imagens 
em torno das palavras "populista" e "popular". Como poderá ser observado, nesse processo de disputa, percebe-se, com clareza, o mecanismo de funcionamento da "política de imagem". Esta é entendida por Gomes (2004) como sendo estratégias formuladas pelos sujeitos políticos para construir a imagem, veiculá-la conforme seus interesses e torná-la hegemônica. Ainda de acordo com 0 autor, ela possui algumas funções que podem ser desempenhadas em etapas ou simultaneamente: "às tradicionais funções substantivas da política agregaram-se as funções relacionadas à imagem: produção, ajuste e administração." (GOMES, 2004, p. 278). Cabe esclarecer que, neste artigo, privilegiouse 0 exame de como essas três funções foram gerenciadas pelos candidatos e seus profissionais de criação de imagem.

No dia 5 de outubro de 2008 , ao ser confirmado o segundo turno na disputa pela prefeitura de Belo Horizonte, o então candidato Leonardo Quintão (PMDB) é chamado de populista por seu adversário Márcio Lacerda (PSB) e reage: "Não sou populista, sou popular". De imediato, tal resposta de Quintão intrigou-nos. Se, de acordo com Ferreira (2001, p. 124), "Populista é sempre o Outro, nunca o Mesmo. Sempre 0 adversário, o concorrente, o desafeto". Assim, por que um político popular poderia ser o Mesmo? 0 que fundaria a positividade dessa imagem em contraposição à imagem pejorativa impregnada no populismo? 0 que estaria ele entendendo por popular? E, ainda, o que Lacerda teria visto de populista em Quintão? Buscar apresentar as reflexões feitas a partir de tais indagações tornouse, então, o motivo e o desafio deste artigo.

De início, há que se situar tais sujeitos, 0 campo de forças no qual o embate se dá e 0 lugar político a partir do qual Lacerda acusa Quintão de populista. A eleição para prefeito em Belo Horizonte foi marcada pela oscilação dos candidatos nas sondagens eleitorais. Leonardo Quintão, no início da propaganda eleitoral, possuía apenas $4 \%$ das intenções de voto - e Márcio Lacerda 40\% -, entretanto, nas últimas semanas que antecederam ao pleito as pesquisas apontavam um crescimento surpreendente do candidato Leonardo Quintão, resultado esse que 0 levou a obter $41,26 \%$ dos votos válidos (excluídos os brancos e nulos), e ficar próximo de Márcio Lacerda que ficou com 43,59\%; configurando-se, assim, um segundo turno.

No decorrer do primeiro turno, Márcio Lacerda, que não dispunha de experiência política no executivo, foi valorizado por sua competência técnica e apresentado como o candidato da "Aliança por BH", de centro-esquerda, entre 0 PSDB e 0 PT. A aposta era a de que 0 governador Aécio Neves (PSDB) e o prefeito Fernando Pimentel (PT) conseguiriam elegê-lo, no primeiro turno, com base na ótima avaliação do eleitor de Belo Horizonte de suas eficientes políticas 
administrativas. Já Leonardo Quintão (PMDB)

- jovem deputado federal de 33 anos e o mais

votado do seu partido -, sem se assumir como

oposição, pelo contrário, apresentava-se, desde

o início de seu HGPE, não só como um grande

admirador do governador Aécio Neves, e como

um candidato que daria continuidade à política

municipal, mas, também, como um candidato

que se preocupava com as pessoas. Em suas

palavras: "Gente cuida de gente. Obras estão por

toda a cidade; eu aplaudo as obras. Mas obras

não cuidam de gente".

Esse cenário de indiferenciação tanto entre

os partidos quanto em relação ao esquema

clássico oposição/situação levou o eleitor, de

acordo com Telles, Storni e Lourenço (2009),

não só a atribuir relevância ao HGPE, como

fonte de informação e expor-se mais ele, mas,

também, a considerar sua avaliação sobre os

programas eleitorais como um dos elementos

mais decisivos no momento de votar.

No âmbito deste artigo, outro significativo

achado da pesquisa - "A decisão de voto em

eleições municipais" ${ }^{2}$ - realizada por esses

autores diz respeito ao modo como o eleitorado

percebia esses candidatos. Leonardo Quintão

"no primeiro turno, destaca-se com Jô Moraes,

por ser o mais preocupado com os mais pobres (16\%); no segundo turno, por ser 0 mais simpático (50\%), e, novamente o mais preocupado com os pobres (40\%)." (TELLES, STORNI, LOURENÇO, 2009, p. 10). Já Márcio Lacerda "no primeiro turno foi localizado à direita (33,5\%); o que defende os mais ricos $(32,8 \%)$. E, no segundo turno, associado novamente ao defensor dos mais ricos (41\%)."(p. 9). Em vista disso, os autores chegam a formular a pertinente sugestão: "Uma das hipóteses que poderá ser explorada futuramente é a de que 0 voto em Belo Horizonte tendeu a ser baseado nas imagens construídas pelos candidatos [no HGPE]" (p. 18).

Isso posto, cabe esclarecer que se optou por buscar responder às perguntas formuladas a partir da análise, em um primeiro momento, do sentido de "populismo" na sátira paródica do HGPE de Quintão, inserida no ambiente do YouTube, pela equipe de Lacerda, às vésperas da eleição em segundo turno, tendo como contraponto o texto parodiado. Tal opção justifica-se por se considerar a produção dessa paródia uma estratégia complexa de desconstrução de imagem que, ao apropriarse do HGPE do adversário, num nível metadiscursivo, produziu uma inversão irônica do programa eleitoral de Quintão, às custas de sua própria produção; materializando sua 
acusação - Quintão é populista - por meio de recursos técnicos e simbólicos. Tal estratégia pode ser apreendida como uma tática adotada com vistas a cumprir, de acordo o marqueteiro Cacá Moreno, um dos objetivos estratégicos, do segundo turno: "fazer o combate ao adversário usando o próprio adversário. Assim, inauguramos a série 'Leonardo X Leonardo', pautada pelas contradições do discurso do candidato". (ZENÓBIO, 2008). A estratégia era "desconstruir a imagem que Quintão criou de si próprio". (PEIXOTO, 2008).

Nesse sentido, de modo pertinente, Albuquerque (1999, p. 77) observa que: "os ataques a adversários invertem a lógica da apologia ao candidato: ao invés de associar 0 próprio candidato a valores positivos, o que se pretende aqui é relacionar os adversários a valores negativos."

Por fim, examina-se o processo de construção da imagem de Quintão, em seu HGPE televisivo, como um candidato "popular". Nesse processo destaca-se o recurso à estética e à linguagem do popular massivo e à exposição de sua vida privada.

\section{2 "Quintão populista": uma sátira paródica no YouTube ${ }^{3}$}

Abril de 2009. 0 portal de notícias do jornal $O$ Tempo informa que Leonardo Quintão entrou com uma ação contra 0 comediante Tom Cavalcanti na $6^{\text {a }}$ Vara Cível de Belo Horizonte por danos morais e uso indevido de imagem. Nas palavras de Quintão: "Ele (Tom) ironizou a minha campanha, debochou do povo mineiro, debochou de mim. Isso foi muito prejudicial para a minha campanha"” (FAGUNDES, 2009).

No dia 22 de outubro de 2008, a quatro dias da eleição em $2^{\circ}$ turno, a equipe de campanha de Márcio Lacerda inseriu no YouTube o vídeo "Leonardo Quintão por Tom Cavalcanti: Genti Cuidando de Genti" (fíg. 1). Esse vídeo ocupou por um dia o sexto lugar entre os mais vistos do mundo (Internet eleva risco de... 2008) e, "até 0 dia 31 de outubro já tinha sido visto por quase um milhão de pessoas." (ZENÓBI0,2008). ${ }^{5}$

Agradeço as contribuições de André Brasil, Céres Castro, Ércio Sena, Márcio Serelle, Mário Viggiano, Júlio Pinto e Silvana Seabra por ocasião da análise do material empírico e a de Edson Cruz, pela revisão.

Importa ressaltar que a Câmara Federal aprovou no dia 8 de julho de 2009 o Projeto de Lei 5498/09 - a ser ainda votado pelo Senado - que contém muitas restrições ao livre uso da internet na política. Os deputados equipararam a internet às emissoras de rádio e TV. "Em blogs e redes de relacionamento social a proposta proíbe o uso de recurso de áudio ou vídeo que, de alguma forma, degradem ou ridicularizem candidato, partido ou coligação" (RODRIGUES,2009).

Esse vídeo foi postado na categoria "Notícias e política" com 11 palavras-chave: Leonardo, Quintão, Belo Horizonte, candidato, prefeito, pmdb, Marcio, lacerda, eleições 2008, eleições, leonardoquintão. Essas palavras selecionadas (sem uso de artigos e conjunções) e também o seu número sugerem-nos conhecimento sobre o modo como alcançar maior visibilidade nesse ambiente. Acessado no dia 24 de junho de 2009, registrava 2341 comentários, tendo sido, o último, inserido três semanas antes, 0 que revela que ele continuou repercutindo. Interessante ainda mencionar que, no dia 21 de outubro, com as mesmas palavras-chave, mas na categoria humor, é inserido no "Paredão do Quintão" o vídeo "BBB do Quintão". Endereço para visualização: www.youtube.com/ paredãodoquintão . 
Figura 1: Imagens do HGPE de Leonardo Quintão e da sátira paródica no YouTube (Disponível em: < www. youtube.com/da um jóia>)
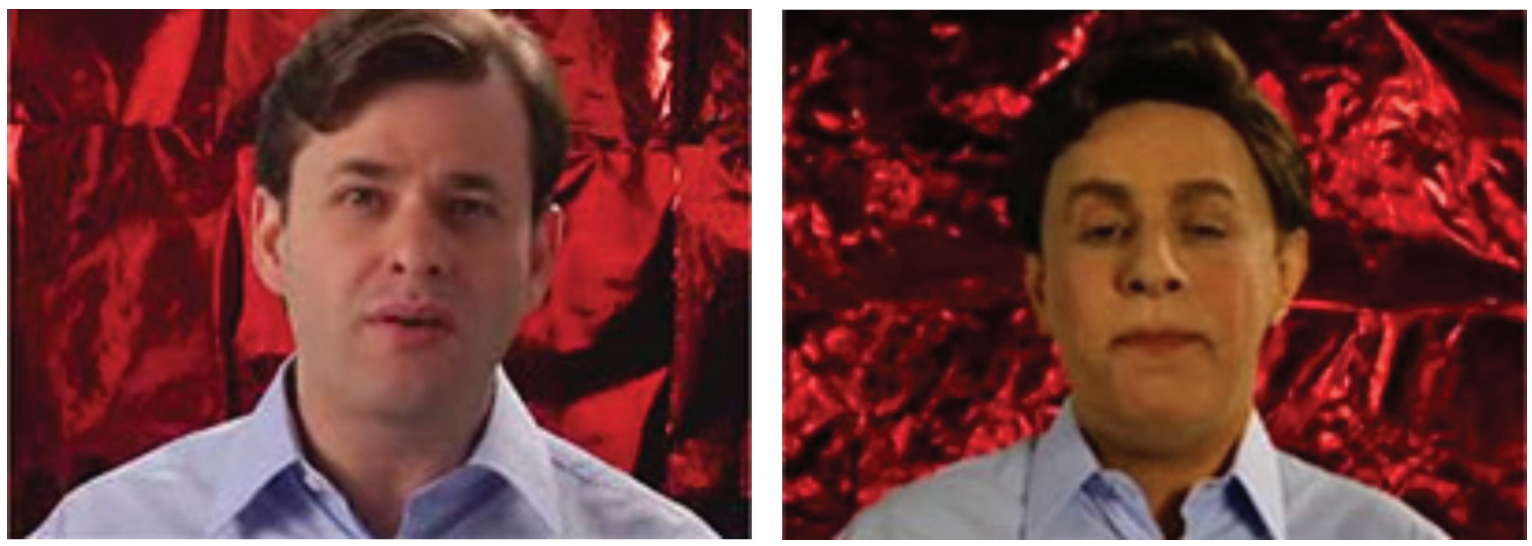

No dia seguinte, matéria publicada pela Folha

correr o risco de perder minutos no último dia

Online detalha esse uso estratégico do YouTube:

da campanha por causa de eventual direito de resposta.(VÍDE0,2008). A outra dizia respeito

No site de Lacerda, a campanha 'comemora' os [70 mil ] acessos do vídeo e 'explica' como foi feito o contato com o comediante.

"Para a produção, o contato com Tom Cavalcanti foi feito no último domingo [19 de outubro] pelo publicitário Paulo Vasconcelos, um dos coordenadores da comunicação do candidato Márcio Lacerda, adversário de Leonardo Quintão na disputa de Belo Horizonte. 0 comediante redigiu 0 roteiro e bateu 0 martelo com Vasconcelos, em seguida. A gravação se deu na terça-feira [21 de outubro]", informa 0 site de Lacerda.

\section{$[\ldots]$}

Procurada pela Folha Online, a campanha de Leonardo Quintão disse não ter conhecimento sobre 0 vídeo e disse que "o candidato em si [Márcio Lacerda\} é uma paródia. Ele é 0 candidato laranja", disse o deputado estadual Sávio Souza Cruz (PMDB), coordenador da campanha de Quintão. (LACERDA, 2008, grifo nosso)

Duas justificativas para escolha da veiculação da paródia no YouTube e, não no HGPE, circularam na mídia. Uma delas era a de que não se poderia ao zelo de não comprometer a estratégia considerada, posteriormente, a decisiva na desconstrução da imagem de Quintão. Nas palavras de Cacá Moreno: "o vídeo não poderia ser usado no horário eleitoral gratuito na TV por contradizer estratégia da campanha de Lacerda que, em programas para a televisão, afirmava que "com política não se brinca" (AUGUSTO, 2008). Tal bordão foi criado a partir de outra campanha negativa veiculada pela equipe de Lacerda, em seu HGPE, apresentada a seguir.

No dia 15 de outubro é liberada pelo TRE, por meio de liminar, a exibição de um vídeo de Leonardo Quintão na convenção do PMDB, em Ipatinga, Minas Gerais, em junho de 2008, fazendo campanha para o pai, Sebastião Quintão (PMDB). No trecho exibido no HGPE, e, nas inserções televisivas de Lacerda, Quintão aparece 
exaltado com o microfone na mão e chamando os presentes a repetir com ele: "Nós vamos ganhar e chutar a bunda deles" e fazia o gesto com as pernas de um chute no ar. No entanto, não informava a quem se referia a provocação, repetida por três vezes. Em seguida, o locutor da campanha de Lacerda pergunta: "É isso que a gente quer para Belo Horizonte?". 0 fato de as imagens terem sido gravadas pelo circuito interno de segurança da Câmara de Vereadores de Ipatinga, e, portanto, em local fechado, levou o Tribunal Regional Eleitoral (TRE-MG) a recusar o pedido de Leonardo de Quintão, via $\mathrm{PMDB}^{6}$, de suspensão da exibição do mesmo. Em sua sentença, a juíza Mariza Porto alega que "as imagens trazidas no feito não são do agravante nem foram geradas por ele, apesar de não terem sido realizadas em estúdio. As imagens são do agravado" (RIZZO, 2008a, p. 3). Na matéria publicada pelo jornal Estado de Minas intitulada "Quintão agora vê 'armação"” são apresentadas duas explicações diferentes dadas por Quintão. A primeira, concedida por ele durante um debate em uma escola de Belo Horizonte: "Segundo ele, sua fala no vídeo era uma brincadeira [...] Sou um brincalhão. Tenho um time de futebol, por exemplo, e, quando nos reunimos, falamos também que vamos chutar a bunda". Nessa mesma matéria é informado que, mais tarde, à imprensa, o candidato disse: "Foi uma armação. 0 áudio não é das imagens da Câmara, que não têm som". (RIZZ0; AUGUSTO, 2008, p. 4) De qualquer modo, parece-nos que a eficácia desse vídeo, na desconstrução da imagem de Leonardo Quintão $0^{7}$, residiu no fato de mostrar que ele, ao desconhecer que tal pronunciamento ganharia a esfera de visibilidade midiática, teria dito suas verdadeiras intenções. E, assim, nesse caso, podese, recorrendo-se a Niklas Luhmann, dizer que

A discrepância entre o pronunciamento público e as intenções reais, que só são manifestadas privadamente, fica em geral assumida. Contra todas as suposições racionalistas sobre 0 efeito de elucidação da verdade, que está no ato de tornar público, esse caso ${ }^{8}$ demonstra que a verdade não reside na comunicação pública, mas na comunicação reservada. (LUHMANN, 2005, p. 81)

De acordo com Steibel (2007, p. 143): "só os partidos políticos podem ocupar o espaço televisivo gratuito e só eles, ou seus membros, podem ganhar ações de Direito de Resposta no Tribunal Eleitoral”. 0 que é visto, pelo autor, como uma prova da importância que o Poder Judiciário atribui aos partidos como instituições democráticas. Interessante tal consideração quando 0 que se presencia, cada vez mais, por parte dos candidatos, é a busca estratégica por desvencilhar suas imagens das dos partidos. Exemplo: 0 presidente Lula nas eleições de 2006. Ainda nesse sentido, é interessante observar como o candidato Leonardo Quintão na construção de seu discurso - populista - também apaga o PMDB.

Em matéria publicada no jornal Estado de Minas, o marqueteiro de Lacerda informa: "0 vídeo definiu muito na classe média. Teve papel finalizador. Foi o 'arremate'[...] foi o responsável para conter a 'avalanche' de Quintão naquele momento contra Márcio Lacerda. (AUGUSTO, 2008)

Esse caso refere-se à situação vivenciada pelo ex-ministro da fazenda brasileiro, Rubens Ricupero, em setembro de 1994. Ano esse de eleições. Uma conversa do então ministro da fazenda com um jornalista da Rede Globo (seu primo) foi captada por antenas parabólicas. 0 ministro teria dito que as declarações públicas sobre 0 Plano Real não corresponderiam às verdadeiras intenções de Fernando Henrique Cardoso, se eleito. 0 ministro foi obrigado a renunciar. Luhmann, em nota, transcreve trecho da matéria publicada pela revista Veja na ocasião: " 0 chato, para o ministro, é que todo mundo sabe, por experiências próprias, que as conversas particulares são muito mais sinceras do que as declarações públicas” (LUHMANN, 2005, p. 81). 
Fato é que a paródia foi inserida em um ambiente de expressiva visibilidade como o YouTube e com 0 recurso de sua rápida disseminação por meio de comunidades do Orkut. Há, ainda, que se considerar 0 caráter de novidade dessa estratégia, uma vez que foi a primeira eleição municipal a qual se pode recorrer a esse ambiente com tal propósito.

Pelo exposto, pode-se considerar que a paródia "Leonardo Quintão por Tom Cavalcanti: Genti Cuidando de Genti" se serviu do HGPE de Quintão como arma, como sugere-nos Yunck ${ }^{9}$, citado por Hutcheon (1985, p. 71): " [há] paródias que se servem do texto parodiado como alvo e as que se servem dele como arma. A última está mais próxima da verdadeira paródia moderna, irônica, alargada". Por fim, cabe mencionar que a equipe de Lacerda, em diversas matérias publicadas na mídia, negava a autoria do referido vídeo, afinal eles também abriram um flanco: também brincaram com a política.

Linda Hutcheon ainda destaca que, "por vezes, a obra parodiada é uma obra risível, pretenciosa, à espera que a esvaziem; mas, as mais das vezes, são as obras com muito êxito que inspiram paródias". (HUTCHEON,1985, p. 97). 0 fato de 0 alvo da paródia ser o programa televisivo de Leonardo Quintão sugere-nos o reconhecimento por parte da equipe de Márcio Lacerda da importância dessa tática tendo em vista a boa performance do adversário na televisão. "Quintão assusta aos rivais pela sua boa postura e habilidade diante das câmeras de TV" (PEIXOTO, 2008). De fato, de acordo com Telles, Storni e Lourenço (2009, p. 21), Leonardo Quintão foi beneficiado pela sua campanha eleitoral no seu HGPE: "em relação aos eleitores que avaliam bem sua propaganda no HGPE, estes têm 8,73 vezes mais chances de se decidirem pelo candidato."

Ao se examinar 0 vídeo e considerar a cena política, pode-se dizer, que, na verdade, trata-se de uma sátira paródica "(um tipo do gênero sátira) que visa algo exterior ao texto, mas que emprega a paródia como veículo para chegar ao seu fim satírico ou corretivo" (HUTCHEON, 1985, p. 83). Na campanha de Lacerda e, também, na mídia ${ }^{10}$, Leonardo Quintão era apresentado, reiteradamente, como um candidato que representava 0 atraso, a demagogia e o populismo. Do mesmo modo, pode-se dizer que esse era 0 alvo extramural da sátira paródica. Curiosamente, ao se examinar 0 vídeo, percebe-se a presença de pelo menos duas diferentes acepções de populismo ancorando às críticas; realmente, como observa

YUNK, J. A. The Two Faces of Parody. Iowa English Yearbook, n. 8, p. 29-37, 1963.

10 Na mídia, isso foi observado, especialmente, no " principal jornal local - o Estado de Minas -, [que] passou a apoiar abertamente a campanha de Lacerda e disseminava informações negativas produzidas pela campanha da "Aliança por BH". (TELLES; STORNI; LOURENÇO, 2009, p. 10). 
Gomes (2001), trata-se de um conceito com um alto grau de plasticidade.

Uma primeira acepção parece-nos operar com uma ideia de populismo próxima a uma concepção liberal elitista "forjada nos horizontes ideológicos da velha classe média brasileira" (WEFFORT, 1989, p. 25). 0 autor elucida tal visão por meio da reprodução de uma fala de um parlamentar liberal que, lastimando os resultados das eleições de 1945 para seu partido, a UDN, sugere aos políticos como se comportar em uma eleição: "evite por todos os meios obrigar o povo a refletir. A reflexão é um trabalho penoso a que o povo não está habituado. Dê-lhe sempre razão. Prometa-lhe tudo o que ele pede e abrace-o quanto puder" (WEFFORT, 1989, p. 24). Ainda, em seu entender, essa visão igualmente se faz presente entre os ideólogos do nacionalismo, que "apesar de suas proclamações de identificação com o povo, definem, em geral, o populismo pelos seus aspectos exteriores - a demagogia, a emocionalidade, a verbiagem social - etc. - e especialmente pela 'ausência de ideologia'. 0 populismo seria, então, mera exterioridade, fato político sem conteúdo" (p. 25).

Nesse sentido, a crítica ao discurso emocional de Quintão é elaborada por meio de uma repetição das palavras amor e coração, e a censura à demagogia é elaborada por meio de uma estratégia de esvaziamento de seu discurso político, em especial, de suas propostas relativas à saúde e ao transporte ${ }^{11}$ direcionadas às camadas populares:

Gente presta atenção. Dá pra fazer!A prefeitura
de Belzonti, quando você tem amor dentro de
você, na saúde. No aspecto do transporte, é de
dentro do coração para fora abraçando as pes-
soas que a gente quer ver dentro do trânsito. Ou
seja, dentro dos carros que estão engarrafados.
0 amor também pode passar pela saúde! É gen-
te ajudando gente. E o amor também!

Já a segunda acepção diz respeito a um outro traço característico do populismo clássico: 0 personalismo, ou seja, a liderança que busca 0 apoio das massas, que apresenta-se como defensora dos interesses sociais de maneira pessoal; sobrepondo-se às instituições formais. No trecho abaixo da paródia a marca do personalismo pode ser observada pelo uso do eu e pelo modo como o candidato se dirigia pessoalmente e individualmente aos eleitores:

Gente, presta atenção, dá pra fazer tudo! Eu vou ter um telefone, do lado da minha cama, que você liga para mim, a hora que você quiser, se eu estiver tomando banho, o fio é tão grande que dá para atender você de dentro do banheiro, tomando banho com o chuveiro.

Gente presta atenção. Com muito carinho, com muito amor, papai sabe disso. Dá pra fazer! A 
Célia... recebi seu e-mail! Célia, aqui de belzonti pergunta: "Dá pra fazer uma lipoaspiração?" Se tiver dinheiro dá pra fazer!

O HGPE de Quintão, do dia 15 de outubro, no segundo turno, ilustra a personificação de seu discurso. Chama-nos a atenção, particularmente, a frase: "eu quero ouvir você através dos sindicatos, através das associações, mas, principalmente, ouvir você direto"; não se utiliza, por exemplo: "nós do PMDB".

Eu quero escutar [aponta com o dedo esquerdo ouvido], eu quero ouvir você através dos sindicatos, através das associações, mas, principalmente, ouvir você direto. Você falando com o prefeito. Porque se eu te escutar, se eu te ouvir, se nós fizermos esse canal de comunicação, muita coisa vai ser resolvida. (grifo nosso)

Já em sua campanha o candidato buscava dar provas disso. Em todos os seus programas televisivos o candidato aparecia conversando com as pessoas na rua, abraçando-as, beijando-as. Mas o elemento novo, nesse sentido, decisivo na eleição de Belo Horizonte foi a demanda pela presença dos candidatos nos inúmeros debates com estudantes organizados pelas escolas. No primeiro turno, Quintão participou de mais de 30 debates enquanto Lacerda não participou de nenhum; isso, inclusive, foi considerado, pela própria equipe de Lacerda, um grave erro estratégico seu.

Corrobora, ainda, nesse sentido, a pertinente colocação de Telles, Storni e Lourenço (2009, p. 23):

Notou-se que o personalismo foi elemento central na propaganda veiculada na televisão, no primeiro turno. 0 partido político permaneceu como adereço, e apenas passou a emergir nas campanhas a partir do segundo turno. 0 PT - partido que apoiava Lacerda - passa a ser apresentado nos programas para fornecer confiança ao eleitor. Tratou-se de usar a sigla em nome de um candidato com atuação nos espaços institucionais (Lacerda) versus um candidato "populista" e descolado das instituições (Quintão).

Interessante, ainda, perceber, na paródia, 0 destaque reservado à ridicularização da proposta de Quintão de apresentar-se como um igual, como gente. Começando pelo seu título, "Leonardo Quintão por Tom Cavalcanti: Genti Cuidando de Genti", e estendendo-se a um de seus trechos no qual se observa, ainda, a reprodução do jeito mineiro, caipira, de falar:

Gente... eu às vezes eu fico pensando na vida. Num é importante tá perto da gente: "purque" é gente fazendo gente. Quando você faz gente você faz um "cado" de "minino". Isso me emociona. Me dá uma vontade de chorar tão grande (chora). É gente chorando por gente.

Curiosamente, no mesmo dia em que a paródia foi postada no YouTube, no dia 22 de outubro, em seu HGPE, Quintão comenta:

Às vezes até as pessoas me criticam, começam a me criticar porque eu falo demais de gente. Mas o que que é gente? Gente são pessoas, são seres humanos. E, você sabe de uma coisa? Eu também sou gente. Eu também tenho sentimentos, acerto, erro, tenho emoção (grifo nosso).

Em suma, a partir de Hutcheon (1985), podese dizer que essa paródia, ao ser abertamente dirigida aos eleitores de Belo Horizonte, buscou 
alcançar o sentido pretendido, num primeiro momento - exposto acima -, levando o internauta ao reconhecimento do texto parodiado por meio da aproximação com o discurso verbal do candidato, da imitação do cenário como fundo vermelho presente nos programas do HGPE de Quintão, na aproximação com sua aparência física: uso do topete - só que de modo acentuado ${ }^{12}$; a mesma cor da camisa, o jeito caipira de falar e a excessiva repetição dos mesmos bordões utilizados pelo candidato: "Gente presta atenção", "Dá pra fazer", por exemplo, e pelo gesto de joia. Num segundo momento, como se verá a seguir, buscou-se um direcionamento explícito de sua interpretação.

Nessa perspectiva, importa ressaltar que, no vídeo, a sátira paródica termina exatamente no momento em que o cenário é substituído pelo branco e o humorista Tom Cavalcanti, em primeiro plano, aparece sem maquiagem e peruca e com uma camisa branca. De modo interessante Perissé (2002), esclarece que: “candidato' é uma palavra que vem do latim candidatus, isto é, vestido de branco (candidus). Na Antiguidade, aquele que disputava um cargo público e precisava angariar votos, vestia-se de branco para simbolizar sua pureza". É como se ele quisesse se despir do seu papel de humorista: não estava ali mais para entreter, ridicularizar Quintão, mas para dizer a verdade; assim como o candidato do
PMDB também deveria fazer. Nesse sentido sua fala final é bem ilustrativa:

Vamos falar sério. Eu vim aqui para dar esse depoimento sem receber nada em troca porque me preocupo com o futuro dessa cidade e com boa parte da minha família que aqui mora. Eu também amo BH! Quando for para fazer personagem me chama, que eu tô na área! Não é de um bom ator que BH está precisando, é de um bom prefeito!

Tal expediente sugere-nos que, dado seu caráter como arma de campanha, buscou-se garantir o sentido pretendido evitando que o vídeo fosse visto como mais uma performance de Tom Cavalcanti no YouTube, cabe lembrar com Hutcheon (1985): uma paródia também pode ser uma forma de elogio; afinal, fazem-se paródias de textos que agradam.

Nesse sentido, enquanto arma, interessa-nos sublinhar a frase final de Tom Cavalcanti: "Não é de um bom ator que BH está precisando, é de um bom prefeito". 0 uso dessa metáfora - "ator" - como argumento final do vídeo sintetiza a tática da equipe de Lacerda para desconstruir a imagem de Leonardo Quintão, explicita a finalidade de sua produção.

Do mesmo modo, é significativo o fato de o HGPE de Lacerda, do dia 14 de outubro, iniciar com a apresentadora esclarecendo: '0 nosso adversário não é, definitivamente, o bom mocinho que finge ser na televisão". 
Em vista do exposto, considera-se estratégica a escolha de um ator para fazer um ator. Temse, aí, de modo curioso, uma representação de segunda ordem caricata: uma referência a uma referência. Mas não de um ator qualquer: recorreu-se a Tom Cavalcanti - descendente de uma linhagem popular de humoristas - que, há quatro anos, comanda o programa, de grande audiência, "Show do Tom", aos fins de semana, na Rede Record. A escolha desse programa sugere-nos que a equipe de Lacerda também fez uma aposta - como Quintão - na eficácia do apelo ao popular massivo $0^{13}$, só que, nesse caso, buscou, ainda, aliar humor e política para estabelecer que o HGPE do adversário era um programa popular, sim, só que de humor.

\section{3 "Quintão popular": a "verdade" na TV}

De início, cabe esclarecer que este formato do HGPE de Quintão - alvo de julgamento irônico no YouTube - foi o terceiro a ser implementado ao longo da campanha. No primeiro formato, a candidatura de Leonardo Quintão é respaldada pelos ministros do PMDB: Hélio Costa, ministro de Estado e Comunicação, e por José Gomes Temporão, ministro da Saúde, e a logomarca do partido aparece em destaque na tela durante todo o programa; o candidato aparece de óculos, terno e gravata discursando no Congresso. Já, no segundo formato, o candidato apresenta suas propostas sentado no sofá da sala de estar da sua casa, e é simulada uma situação de conversa com um rapaz, mas que apenas o escuta; usa camisa social com a manga dobrada e a logomarca do PMDB continua em destaque. Nesses dois primeiros modelos se sobressaía o processo de edição: 0 uso de efeitos tecnológicos. A Coordenadora de Comunicação da campanha, Ana Paula Santos, esclarece o motivo dessa mudança do primeiro para 0 segundo formato; em sua explicação, chama-nos a atenção a ausência de um cálculo estratégico no sentido de que estariam dando um passo interessante - como será discutido adiante - em termos de midiatização:

Estávamos tendo dificuldades para estabelecer uma sintonia entre 0 candidato e a câmera. Já que ele tinha dificuldade de transparecer suas ideias com clareza e verdade, com textos roteirizados. [Assim] fizemos uma gravação sem roteiro no estilo bate-papo, que foi gravado na sala residencial do candidato. Deste bate-papo foram elaborados outros programas, já que esta postura do candidato, sem tele-prompter e mais à vontade, trouxe maior clareza e aceitação de suas ideias.

Já o terceiro formato - referenciado na análise da paródia - foi implementado, no dia 1 de setembro, pela marqueteira Silvana Machado Coelho, ao assumir a campanha em substituição a Cacá Souza. De acordo com ela, tal formato teve origem na ideia de que "gente cuida de 
gente" e surgiu a partir de um erro estratégico na construção da imagem de Lacerda:

As eleições municipais de BH em 2008 pareciam previamente definidas. Um candidato indicado pela aliança entre o governador e 0 prefeito (ambos com altos índices de popularidade) alcançava $40 \%$ das intenções de voto. 0 povo parecia conformado com a ideia de continuidade. Não se via discussão política nem novos anseios. Por outro lado, tínhamos um candidato perdido no "limbo" do desconhecimento ( $4 \%$ nas intenções de voto) e do desinteresse do eleitor. Foi, nesse momento, que fomos convidados a participar da campanha de Leonardo Quintão. Como vencer essa inércia? 0 que poderia interessar ao eleitor além desse universo de poder conhecido e aparentemente confortável? 0 que poderia fazer frente a uma máquina tão bem azeitada e tão "obreira"? Havia um ponto a ser considerado. Não eram o governador nem o prefeito que estavam disputando as eleições. A aliança, que parecia inabalável, tinha um furo. Ela parecia maior que seu candidato. Parecia estar a serviço de si mesma. Percebemos aí uma pequena chance. As pessoas votam em pessoas. E 0 Leonardo era um mineiro típico ${ }^{14}$, uma pessoa de bem ${ }^{15}$ (grifos nossos).

Em vista disso, de início, buscou-se, assim, concretizar tal tática no HGPE:

Percebemos que 0 melhor do Leonardo era 0 próprio Leonardo. Procuramos "limpar" o programa. Deixar que 0 Leonardo aparecesse. 0 cenário simples, apenas um painel de laminado vermelho que lembrava os balões em forma de coração, usados nos clipes e caminhadas. Câmera parada e plano fechado no candidato. Nada que pudesse desviar a atenção do olho no olho, da conversa franca. Era hora de apresentar o homem.Torná-lo reconhecível e mostrá-lo acessível. (grifos nossos)

Ao articular essas duas falas de Silvana Coelho, percebe-se, com clareza, que se pretendeu estabelecer a ideia de que 0 candidato era um típico mineiro - com sotaque caipira, inclusive -: simples, honesto, verdadeiro, tanto ao nível da linguagem televisiva quanto ao nível de seu discurso político. Há que se considerar que, na análise do discurso político na TV, "em consonância e/ou dissonância com a linguagem verbal, o corpo, as imagens e a tela participam da produção de sentidos" (COURTINE apud PIOVEZANI FILHO, 2007, p. 4) Nesse sentido, o trecho, abaixo, de seu HGPE, do dia 22 de outubro, reta final da campanha, pode ser lido como uma tentativa de reparar 0 dano a essa sua imagem acarretado pela veiculação, dias antes, do vídeo "Chute na Bunda" pela equipe de Lacerda ${ }^{16}$ :

Olha, gente, quero falar a respeito da verdade com você. E verdade, é o seguinte: é respeitar você. É olhar no olho e falar coisas que eu posso fazer e também falar para você as coisas

Oportuno mencionar que Silvana Coelho conhecia bem o discurso da mineiridade. Em 2000, recebeu o prêmio "Colunistas Centro-0este" como diretora de arte, juntamente com Waldemar França, pela série de propagandas "Edgar e Norma", da agência DNA para a Telemig Celular, estruturada na exploração dos valores caros aos mineiros.

Nesse sentido, é muito interessante o modo como o então prefeito Fernando Pimentel, após confirmada a vitória de Lacerda, caracterizou a Aliança PT-PSDB: “trata-se de uma tese política, não necessariamente eleitoral” (ARRIEL,2008,p.36)

De modo curioso, importa ressaltar que a pesquisa "A decisão de voto em eleições municipais" consegue captar junto ao eleitorado de Belo Horizonte, no segundo turno, a percepção de que Quintão não estaria sendo honesto: "para 36\% ele é considerado o candidato que mais mente (36\%)" (TELLES; STORNI; LOURENÇ0, 2009, p. 9). 
que eu não posso fazer. E é isso que eu tenho feito no meu programa. Você está votando em mim por causa da verdade que eu estou dizendo para você. Aqui o que você está vendo sou eu e... [aponta] a câmera. Não tem, aqui, roteiro, não tem ninguém falando o que dizer. Sou eu e você". Do lado de lá tem os poderosos, temos homens fortes, tem os grandes marqueteiros. ${ }^{17}$ E estou eu aqui ó, ETA eu aqui ó, olhando para você. Preste atenção. Presta atenção no que eu estou falando. Olhe no meu olho aqui, se eu não estou falando a verdade para você. Eu estou pronto e preparado para ser 0 seu prefeito. Sabe porquê? Porque eu quero ser o herói dos meus filhos [...] Eu quero ser herói dos meus filhos. Quero poder voltar para casa de peito aberto, e dizer: "Meu bem, fiz o melhor hoje". Pude ajudar muita gente. [...] No início da campanha eu disse: para ganha desse povo só um milagre de Deus. Mas eu confio em Deus.

Cabe destacar que falas longas como essa, com repetição de ideias e palavras, sem edição, 0 uso de uma retórica do direto ${ }^{18}$ e 0 modo como recorreu à cotidianidade familiar - "lugar social de uma interpelação fundamental para os setores populares" (MARTIN-BARBER0, 2006, p. 295) -, foram as marcas dessa estratégia de apresentar um candidato que dizia a verdade. No caso de Quintão funcionava assim: a partir da sugestão de algumas palavras e/ou perguntas formuladas por Silvana Coelho o candidato elaborava suas respostas. No HGPE do dia 3 de setembro, relata, com detalhes, o modo como conheceu sua esposa, o namoro, as brigas, seu casamento e 0 dia em que seu filho, João Victor, teve um ataque epilético quando foi passear com ele na padaria.

Silvana Coelho informou que tal relato foi proferido a partir da seguinte pergunta: qual foi 0 dia mais triste de sua vida? Ele começa a narrar o fato e diz "pô eu vou chorar" e chora - ocorrenos que em outras circunstâncias, um candidato não faria tal anúncio: choraria. De acordo com a marqueteira, na ocasião ela ficou atônita e todos os que estavam no estúdio se emocionaram; dado o teor do relato, ponderou muito com sua equipe se deveria levar ao ar esse depoimento. Segundo ela, a decisão por sua veiculação se pautou pela sinceridade expressada por Quintão. Ele era "um candidato que buscava recuperar valores do povo mineiro: a família, Deus, o caráter, a simplicidade, atitudes generosas, a honestidade". Importa ressaltar que, na paródia, também se faz menção, de modo debochado, a esses valores: família, Deus, simplicidade e honestidade. Com relação a esse último, é ilustrativo o seguinte trecho da paródia: "Gente, presta atenção, eu nasci muito pobre, liso. Eu era tão magro que meu pai me tirou três vezes da boca do gado". A partir de Canclini (2003, p. 264), poder-seia visualizar, aí, características próximas a um populismo estatizante. Neste, segundo 0 autor "os valores tradicionais do povo assumidos e representados pelo Estado, ou por um líder carismático, legitimam a ordem que estes últimos 
administram e dão aos setores populares a confiança de que participam de um sistema que os inclui e os reconhece."

A partir do exposto, cabe retomar a pergunta inicial: por que Quintão poderia ser o Mesmo? 0 que ele e sua equipe estariam entendendo por político popular? Sua marqueteira, Silvana Coelho, ao ser indagada a esse respeito responde:

Leonardo ia para rua e sentia 0 carinho das pessoas. Era muito impressionante. 0 povo se aglomerava, queria tirar fotos, perguntar coisas, beijar, abraçar. Se sentiam próximas dele. Era popular. Era o homem público. Já o Márcio, quando ia para rua, ia de carro, não conseguia sorrir, não se misturava. Era o candidato das elites. Do poder estabelecido. Definitivamente não era popular.

De modo curioso, um trecho da paródia parece reiteirar - às avessas - esse entendimento de que Quintão seria um político popular por ser carismático, estimado pelas pessoas, "ter ibope" junto a essas: "Gente, no dia da eleição, você vai ver minha foto e num vai lembrar de mim.

Eu lembro de você! Deixa eu bater uma foto sua gente. Dá um jóia assim, ó. Segura, vai! [Tom Cavalcanti pega a máquina e dá um click]. Aí! É gente batendo foto de gente". Ocorre-nos, a partir de Canclini (2003), que tanto a equipe de Quintão, quanto a de Lacerda, no que diz respeito à noção de popular, operaram com a mesma lógica da mídia - e, também, do mercado do marketing político -: popular como popularidade. De modo bastante sugestivo Canclini (2003, p. 259) esclarece:

A noção de popular construída pelos meios de co-
municação, e em boa parte aceita pelos estudos
nesse campo, segue a lógica do mercado. "Popu-
lar" é o que vende maciçamente, o que agrada a
multidões. A rigor, não interessa ao mercado e à
mídia o popular e, sim, a popularidade.

Pelo exposto, parece-nos que o sentido de "popular", no caso de Leonardo Quintão, comporta dois sentidos. Um primeiro, próprio aos campos da mídia e do marketing político e conceituado, de modo pertinente, por Canclini, nessa citação acima, refere-se a "popular" como sinônimo de "popularidade": Quintão obteve uma popularidade como a de um ator de televisão com o qual as pessoas queriam tirar foto. E, um segundo sentido, apontado ao longo da análise, e trabalhado por Martín-Barbero (2006), que entende "popular" como "popular-massivo" por seu recurso à cotidianidade familiar e ao melodrama.

Por fim, importa-nos destacar que, a nosso ver, a incorporação no segundo e terceiro formatos - ainda que de modo não conscientemente planejado - do espetáculo, "de uma política da vida privada" ${ }^{" 19}$ foi 0 elemento central da construção da imagem pública política de Quintão. Imagem essa alicerçada nos valores

Essa política, de acordo com Courtine (2003, p. 24), consiste na "exibição da intimidade doméstica e psicológica na qual a política se banaliza nas pequenas coisas cotidianas, se enuncia nos discursos ordinários, se dissemina nos traços quase imperceptíveis da fisionomia". 
de "sinceridade" e "simplicidade". De modo apropriado, Piovezzani Filho (2007) considera que essa mudança em direção à disputa de valores deve ser vista como expressiva do modo de fabricar e expor o "eu" na política contemporânea. São essas ações "que apontam para o deslocamento relativo da fonte de credibilidade e legitimidade, de algum modo, passa-se da função pública aos atributos pessoais" (PIOVEZANI FILHO, 2007, p. 9). Nesse sentido, ocorre-nos que, dada a importância conferida pelo eleitor de Belo Horizonte ao HGPE e às imagens aí construídas - captadas pela pesquisa de Telles, Storni e Lourenço (2009) - 0 que pode ter derrotado Quintão não foi o modo - espetacularizado - como expôs seu "eu", sua intimidade, a personificação de seus discursos que privilegiavam o cotidiano, o ordinário e a linguagem do melodrama na TV, mas a habilidade de seu adversário na desconstrução do que estava por detrás de tudo isso: sua imagem pública política alicerçada em um "eu" verdadeiro. Pode-se, ainda, dizer que essa estratégia de desconstrução do adversário foi elaborada a partir de um discurso de ordem moral. De modo interessante Marilena Chauí salienta que "a personalização do poder acaba pondo em evidência paixões, vícios e virtudes porque restam somente critérios morais para se avaliar a ação e a reação das forças políticas" (CHAUÍ, 1992, p. 382). Assim, ocorre-nos que como contra estratégia a discurso "personalista" de Quintão a equipe de Lacerda produziu um discurso pautado por critérios morais com ênfase num vício atribuído ao adversário: a mentira.

É oportuno, ainda, sublinhar como este estudo de caso nos fez perceber a necessidade de entender melhor 0 entrelaçamento das palavras "populista", "popular" e "popularidade" quando se trata de examinar discursos políticos.

\section{Referências}

ALBUQUERQUE, Afonso de. "Aqui você vê a verdade na tevê". A propaganda política na televisão. Niterói: Universidade Federal Fluminense, 1999.

ARRIEL, Silvânia. No ritmo de Lacerda. Viver Brasil. Belo Horizonte, ano 1. n.1. p. 30-37, nov., 2008.

AUGUSTO, Leonardo. Marqueteiro de Lacerda revela estratégias de campanha. Portal Uai, 02 nov. 2008. Disponível em: http://wwo.uai.com.br/UAI/ html/sessao 20/2008/11/02/em noticia interna,id $\underline{\text { sessao }=20 \& i d \text { noticia }=86169 / \text { em noticia interna. }}$ shtml. Acesso em: 11 fev.2009.

CANCLINI, Néstor Garcia. Culturas híbridas: estratégias para entrar e sair da modernidade. São Paulo: Edusp, 2003.

CARVALHO, Rejane V. A. Política de imagem e competividade eleitoral: a disputa pela prefeitura de Fortaleza em 2000. In: (org.) A produção da política em campanhas eleitorais: eleições municipais de 2000. Campinas: Pontes; Fortaleza: Programa de Pós-graduação em Sociologia da Universidade Federal do Ceará, 2003. CHAUÍ, Marilena. Público, privado, despotismo. In: NOVAES, Adauto (org.). Ética. São Paulo: Companhia das Letras; Secretaria Municipal de Cultura, 1992. p. 345-390. 
COELHO, Silvana. Silvana Coelho: entrevista [jul. 2009]. Entrevistadora: Teresinha Maria de Carvalho Cruz Pires. [S.I.]: [s.n.], 2009.

COURTINE, Jean-Jacques. Os deslizamentos do espetáculo político. In: GREGOLIN, Maria do Rosário. Discurso e mídia: a cultura do espetáculo.São Carlos: Claraluz, 2003.

FAGUNDES, Ezequiel. Quintão vai à Justiça contra Tom Cavalcanti por dano moral. 0 Tempo 0nline, 4 abr. 2009. Disponível em: $\leq$ http://www.otempo.com.br/otempo/ noticias/?IdNoticia=107407>. Acesso em: 4 abr. 2009.

FERREIRA, Jorge. 0 nome e a coisa: o populismo na política brasileira. In: (org.). 0

populismo e sua história: debate e crítica. Rio de Janeiro: Civilização Brasileira, 2001.

GOMES, Angela de Castro. 0 populismo e as ciências sociais no Brasil: notas sobre a trajetória de um conceito.. In: FERREIRA, Jorge (Org.). 0 populismo e sua história: debate e crítica. Rio de Janeiro: Civilização Brasileira, 2001.

GOMES, Wilson. Transformações da política na era da comunicação de massa. São Paulo: Paulus, 2004.

HUTCHEON, Linda. Uma teoria da paródia. Rio de Janeiro; Edições 70, 1985.

INTERNET eleva risco de campanha negativa para candidatos. Folha de S. Paulo, São Paulo, p. A-7, 10 nov. 2008. Caderno Brasil.
LACERDA usa Tom Cavalcanti para imitar Quintão; vídeo já tem 70 mil acessos no YouTube. Folha Online, 23 out. 2008,18h18min. Disponível em :<http://tools.folha.com.br/print?site=emcima dahora\&url=http\%3A\%2F52Fwww1.folh $>$. Acesso em: 11 fev. 2009.

\section{LUHMANN, Niklas. A realidade dos meios de} comunicação. São Paulo: Paulus, 2005.

\section{MARTIN-BARBERO, Jesús. Dos meios às} mediações: comunicação, cultura e hegemonia. Rio de Janeiro: UFRJ, 2006.

MIGUEL, Luis Felipe. Mito e discurso político. Campinas: Unicamp; São Paulo: Imprensa Oficial, 2000.

PEEMEDEBISTA cresceu depois de mudar de marqueteiro e assumir seu "jeito caipira". Folha Online, 6 out. 2008, 11h13min. Disponível em: $<$ http://wwwl.folha.uol.com.br/folha/brasil/ ult96u452931.shtml>. Acesso em: 11 fev. 2009.

PEIXOTO, Paulo. Novo coordenador quer "apresentar" Lacerda a BH. Folha Online, 12 out. 2008, 10h34 min. Disponível em:<http://wwwl.folha.uol.com.br/folha/ brasil/ult96u455228.shtml>. Acesso em: 18 jun. 2009.

PERISSÉ, Gabriel. A arte de adivinhar o passado à luz da etimologia. KPlus, n. 32, 01 abr. 2002. Disponível em: $\leq$ http://Kplus.cosmo.com.br/materia. asp?c0 $=60 \& \mathrm{rv}=$ Colunistas $>$. Acesso em: 28 jun. 2009.

PIOVEZANI FILHO, Carlos Félix. Metamorfoses do discurso político contemporâneo: por uma nova perspectiva de análise. Revista da ABRALIN, v.6, n.1, p.25-42, jan./jun. 2007. Disponível em:< http://www. abralin.org/revista/RV6N1/04-Carlos-Piovezani.pdf> Acesso em: 11 fev. 2009. 
RODRIGUES, Fernando. Blog do Fernando

Rodrigues. São Paulo: Folha de São Paulo, 2009.

Disponível em: <http://uolpolitica.blog.uol.com.br. 9/07/2009>. Acesso em: 8 jul. 2009.

RIZZ0, Alana. TRE autoriza uso de vídeo polêmico. Portal Uai, Belo Horizonte, 16 out. 7h21min., 2008a. Disponível em: < $\underline{\text { http://wwo.uai.com.br/UAI/html/ }}$ sessao_20/2008/10/16/em_noticia_interna,id_ $\underline{\text { sessa0 }=20 \& i d \text { noticia }=83692 / \text { em noticia interna. }}$

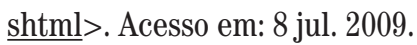

RIZZ0, Alana; AUGUSTO, Leonardo. Quintão agora vê 'armação'. Estado de Minas, Belo Horizonte, p. 4, 16 out $2008 b$.

SANTOS, Ana Paula. Ana Paula Santos: entrevista [jul. 2009]. Entrevistadora: Teresinha Maria de Carvalho Cruz Pires. [S.l.]: [s.n.], 2009.

STEIBEL, Fabro. Feios, sujos e malvados: políticos, juízes e a campanha eleitoral de 2002 na TV. Rio de Janeiro: E-pappers, 2007.

TELLES, Helcimara de Souza; STORNI, Tiago Prata; LOURENÇO, Luiz Cláudio. Partido, campanha e voto: como o eleitor decide nas municipais.

Revista Sociedade e Cultura (Dossiê eleições, representação política e democracia), Goiás, v. 12, n.1, 2009. Disponível em: <http://www.revistas.ufg. br/index.php/fchf/announcement/view/65>. Acesso em: 01 jul. 2009.

VÍDEO de Tom Cavalcante imitando Quintão vira hit na internet. Folha Online, 23 out. 2008, 21h41min. Disponível em: <http://tools.folha.com.br/print?site= emcimadahora\&url=http\%3A\%2F5\%2Fwww... Acesso em: 17 fev. 2009.

\section{WEFFORT, Francisco. 0 populismo na política}

brasileira. 4. ed. Rio de Janeiro: Paz e Terra, 1989.

ZENÓBIO, Edison. Os bastidores da campanha de Márcio Lacerda. Portal Uai, 16 out. 2008, 7h21 min. Disponível em: < http://wwo.uai.com.br/UAI/ html/sessao 4/2008/11/02/em noticia interna,id $\underline{\text { sessa } 0}=4 \& i d$ noticia $=86116 /$ em noticia interna.

shtml >. Acesso em:8 jul. 2009.

MICHAELIS - Moderno Dicionário da Língua

Portuguesa. Disponível em: http://michaelis.uol.com.

br/moderno/portugues/index.php?lingua=portuguesportugues\&palavra=topete. Acesso em: 01 jul.2009. 
"Populist no, popular!: political-electoral images in dispute on YouTube and on TV

\section{Abstract}

This article deals with the mediatization of the political discourse in Belo Horizonte's municipal electoral campaign in 2008, more specifically, of the discursive strategies of (de)construction of mobilized images by two of the candidates. Those strategies were considered singular and excellent for evidencing transformations in the speech and the way of production of politics with the appropriation of the new media. In the case, to examine a complex strategy of negative campaign in YouTube's environment: a parodist satire that uses the free political electoral programs (Horário Gratuito Político Eleitoral - HGPE) of the adversary, in a metadiscursive level; either by appealing to the massive popular aesthetics and the language as an image construction strategy in television programs. It also interests us to show how these media strategies, so contemporary, covered the old and traditional populist speech.

\section{Keywords}

Political speech. Political images. Municipal electoral campaign. Negative campaign.

Politics mediatization.
"Populista no, popular!": imágenes político-electorales en disputa en YouTube y en la televisión

\section{Resumen}

El artículo trata de la mediatización del discurso político en la campaña electoral municipal de Belo Horizonte, de 2008, más específicamente, de las estrategias discursivas de (des)construcción de imágenes movilizadas por dos de los candidatos. Esas estrategias son consideradas singulares y relevantes porque evidencian transformaciones en el discurso y en el modo de producción de la política, sea por la apropiación de los nuevos medios - en este caso, se examina una estrategia compleja de campaña negativa en el ambiente de YouTube: una sátira paródica que se apropia del Horario Gratuito Político Electoral (HGPE) del adversario, en un nivel metadiscursivo; sea por el recurso a la estética y al lenguaje del popular masivo como estrategia de construcción de imagen en el HGPE de la televisión. Nos interesa, aún, demostrar cómo esas estrategias mediáticas, tan contemporáneas, recubrieron el vejo y tradicional discurso populista.

\section{Palabras clave}

Discurso político. Imágenes políticas. Campaña electoral municipal. Campaña negativa.

Mediatización de la política. 


\section{Expediente}

A revista E-Compós é a publicação científica em formato eletrônico da Associação Nacional dos Programas de Pós-Graduação em Comunicação (Compós). Lançada em 2004, tem como principal finalidade difundir a produção acadêmica de pesquisadores da área de Comunicação, inseridos em instituições do Brasil e do exterior.
E-COMPÓS I www.e-compos.org.br I E-ISSN 1808-2599

Revista da Associação Nacional dos Programas de Pós-Graduação em Comunicação. Brasília, v.12, n.3, set./dez. 2009.

A identificação das edições, a partir de 2008 passa a ser volume anual com três números.

\section{CONSELHO EDITORIAL}

Afonso Albuquerque

Universidade Federal Fluminense, Brasil

Alberto Carlos Augusto Klein

Universidade Estadual de Londrina, Brasi

Alex Fernando Teixeira Primo

Universidade Federal do Rio Grande do Sul, Brasil

Alfredo Vizeu

Universidade Federal de Pernambuco, Brasi

Ana Carolina Damboriarena Escosteguy

Pontifícia Universidade Católica do Rio Grande do Sul, Brasil

Ana Silvia Lopes Davi Médola

Universidade Estadual Paulista, Brasil

André Luiz Martins Lemos

Universidade Federal da Bahia, Brasil

Ângela Freire Prysthon

Universidade Federal de Pernambuco, Brasil

Antônio Fausto Neto

Universidade do Vale do Rio dos Sinos, Brasil

Antonio Carlos Hohlfeldt

Pontifícia Universidade Católica do Rio Grande do Sul, Brasil

Arlindo Ribeiro Machado

Universidade de São Paulo, Brasil

César Geraldo Guimarães

Universidade Federal de Minas Gerais, Brasi

Cristiane Freitas Gutfreind

Pontifícia Universidade Católica do Rio Grande do Sul, Brasil

Denilson Lopes

Universidade Federal do Rio de Janeiro, Brasil

Eduardo Peñuela Cañizal

Universidade Paulista, Brasil

Erick Felinto de Oliveira

Universidade do Estado do Rio de Janeiro, Brasil

Francisco Menezes Martins

Universidade Tuiuti do Paraná, Brasil

Gelson Santana

Universidade Anhembi/Morumbi, Brasil

Goiamérico Felício

Universidade Federal de Goiás, Brasil

Hector Ospina

Universidad de Manizales, Colômbia

Herom Vargas

Universidade Municipal de São Caetano do Sul, Brasil

leda Tucherman

Universidade Federal do Rio de Janeiro, Brasil

Itania Maria Mota Gomes

Universidade Federal da Bahia, Brasil

Janice Caiafa

Universidade Federal do Rio de Janeiro, Brasil

Jeder Silveira Janotti Junior

Universidade Federal da Bahia, Brasil
João Freire Filho

Universidade Federal do Rio de Janeiro, Brasil

John DH Downing

University of Texas at Austin, Estados Unidos

José Luiz Aidar Prado

Pontifícia Universidade Católica de São Paulo, Brasil

José Luiz Warren Jardim Gomes Braga

Universidade do Vale do Rio dos Sinos, Brasi

Juremir Machado da Silva

Pontifícia Universidade Católica do Rio Grande do Sul, Brasil

Lorraine Leu

University of Bristol, Grã-Bretanha

Luiz Claudio Martino

Universidade de Brasília, Brasil

Maria Immacolata Vassallo de Lopes

Universidade de São Paulo, Brasil

Maria Lucia Santaella

Pontifícia Universidade Católica de São Paulo, Brasil

Mauro Pereira Porto

Tulane University, Estados Unidos

Muniz Sodre de Araujo Cabral

Universidade Federal do Rio de Janeiro, Brasil

Nilda Aparecida Jacks

Universidade Federal do Rio Grande do Sul, Brasil

Paulo Roberto Gibaldi Vaz

Universidade Federal do Rio de Janeiro, Brasil

Renato Cordeiro Gomes

Pontifícia Universidade Católica do Rio de Janeiro, Brasil

Ronaldo George Helal

Universidade do Estado do Rio de Janeiro, Brasil

Rosana de Lima Soares

Universidade de São Paulo, Brasil

Rossana Reguillo

Instituto Tecnológico y de Estudios Superiores do Occidente, México

Rousiley Celi Moreira Maia

Universidade Federal de Minas Gerais, Brasil

Samuel Paiva

Universidade Federal de São Carlos, Brasil

Sebastião Albano

Universidade Federal do Rio Grande do Norte, Brasil

Sebastião Carlos de Morais Squirra

Universidade Metodista de São Paulo, Brasil

Simone Maria Andrade Pereira de Sá

Universidade Federal Fluminense, Brasi

Suzete Venturelli

Universidade de Brasília, Brasil

Valério Cruz Brittos

Universidade do Vale do Rio dos Sinos, Brasil

Veneza Mayora Ronsini

Universidade Federal de Santa Maria, Brasil

Vera Regina Veiga França

Universidade Federal de Minas Gerais, Brasi

\section{COMISSÃO EDITORIAL}

Felipe da Costa Trotta I Universidade Federal de Pernambuco, Brasil Rose Melo Rocha I Escola Superior de Propaganda e Marketing, Brasil

\section{CONSULTORES AD HOC}

Arthur Autran Franco de Sá Neto I Universidade Federal de São Carlos

Carlos Eduardo Franciscato I Universidade Federal de Sergipe

Elisa Reinhardt Piedras I Universidade Federal do Rio Grande do Sul

Elizabeth Bastos Duarte I Universidade Federal de Santa Maria

Marcia Benetti Machado I Universidade Federal do Rio Grande do Sul

Sandra Maria Lúcia Pereira Gonçalves I Universidade Federal do Rio Grande do Sul

Suzana Kilpp I Universidade do Vale do Rio dos Sinos

Tattiana Gonçalves Teixeira I Universidade Federal de Santa Catarina

Vander Casaqui I Escola Superior de Propaganda e Marketing

Vicente Gosciola I Universidade Anhembi Morumbi

Walter Teixeira Lima Junior I Fundação Cásper Líbero

REVISÃO DE TEXTO E TRADUÇÃO I Everton Cardoso

EDITORAÇ̃̃ ELETRÔNICA I Raquel Castedo
COMPóS I www.compos.org.br

Associação Nacional dos Programas de Pós-Graduação em Comunicação

Presidente

Itania Maria Mota Gomes

Universidade Federal da Bahia, Brasil

itania@ufba.br

Vice-presidente

Julio Pinto

Pontifícia Universidade Católica de Minas Gerais, Brasil

juliopinto@pucminas.br

Secretária-Geral

Ana Carolina Escosteguy

Pontifícia Universidade Católica do Rio Grande do Sul, Brasil

carolad@pucrs.br 